\title{
Analysis of Cow's Urine for Detection of Lipase Activity and Anti-Microbial Properties.
}

\author{
Saneesh Kumar \\ Azyme Biosciences Prv. Ltd., Jayanagar, Bangalore - 560069, Karnataka, India
}

\begin{abstract}
There is enormous amount of literature in Ayurveda stating the importance of cow's urine for all purposes, including its importance in our daily life. This research targets on the antimicrobial activity of urine and its biochemical content that can be the key potential factor for its usage as a medicine.

A detailed biochemical analysis of cow's urine was done to understand its antibacterial/antifungal properties along with lipase activity which could make it a potentially effective anti-cancer agent.

Various micro-organismal plating techniques were applied using Nutrient and Potato Dextrose Agar as the medium for bacterial and fungal growth, to study the inhibitory activity of cow's urine on these organisms. Thin layer chromatography, Volumetric analysis, Spectrophotometric analysis and Tributyrin tests were conducted on cow's urine sample to analyze the lipase activity present within the urine content.

Statistical comparisons, of the spectra obtained from the Spectrophotometric analysis of urine sample, were made with those already analyzed on various types of lipase activity detections from previous researches, and similarities were observed in both studies to ascertain the lipase factor potential within cow's urine sample. The tests proved that cow's urine was highly effective in inhibiting bacterial and fungal growth and also a potential natural source of lipase enzyme.
\end{abstract}

Keywords: Anti-fungal, Ayurveda, Cow's urine, Lipase, Skin-disease.

\section{Introduction}

Cowpathy (Sanskrit: Panchagavya) is a treatment based on the products obtained from cows, used in Ayurvedic medicine. ${ }^{[1]}$. Cow's urine (Sanskrit: Gomutra) is being used as an effective medicine. Recent researches prove that cow's urine therapy is capable of curing several diseases, including certain types of cancer. ${ }^{[2]}$.

Ancient literature in Ayurveda states that cow's urine is one of the best natural remedies to cure many bacterial and fungal diseases, ${ }^{[3] .}$ especially skin diseases. Research states cow's urine to contain nitrogen, sulphur, phosphate, sodium, manganese, carbolic acid, iron, silicon, chlorine, magnesium,citric, titric, succenic, calcium salts, Vitamins A, B, C, D and E, minerals, lactose, enzymes, creatinine, hormones, urea and gold acids. Urea, a key chemical in urine, is known to kill fungi and bacteria. This is the principle behind Gomutra being an effective fungicide as well as antibacterial agent: $;{ }^{[4] \cdot}$ the urine micturated first (early morning) would have more macro and micronutrients along with other enzyme/urea content ${ }^{[5]}$ that could make it more effective as a fungicide.

Current researches even exploit the enzymatic activity of the same, indicating that this natural source of enzymes and nutrients can cure many diseases including cancer. ${ }^{[6] . ~[7] . ~}$

In the rural villages on India, cow's urine is being used since a very long time, as an effective antiseptic for wounds, skin diseases, bathing, etc. In rural houses, people dilute cow's urine with water and use it as a natural disinfectant to purify their premises. With an approximate shelf life of around 5 years, this can prove to be the most effective natural antiseptic and disinfectant, when compared to the synthetic chemicals that are currently available to the consumers. It strengthens the fact that cow's urine is not a toxic effluent, $95 \%$ of its content being water, $2.5 \%$ of urea, and the remaining $2.5 \%$ a mixture of minerals, salts, hormones and enzymes. ${ }^{[8]}$.

Research also proves that cow's urine augments B- and T-lymphocyte blastogenesis, and $\operatorname{IgG}, \operatorname{IgA}$ and IgM antibody titers in mice. It also increases secretion of interleukin-1 and interleukin- $2,{ }^{[9]}$ phagocytic activity of macrophages, and is thus helpful in the prevention and control of infections.

\section{Materials Required}

1. Cow's urine samples from local cows, were collected early morning at around 5am (Fig. A, 1) when cows micturated first time in the day, in sterilized containers. Compared to a sample taken in noon (Fig. A, 2) this would prove more effective.

Note: For this research, urine extracts from local cows from Palakkad district in Kerala and Bangalore, Karnataka were taken. 


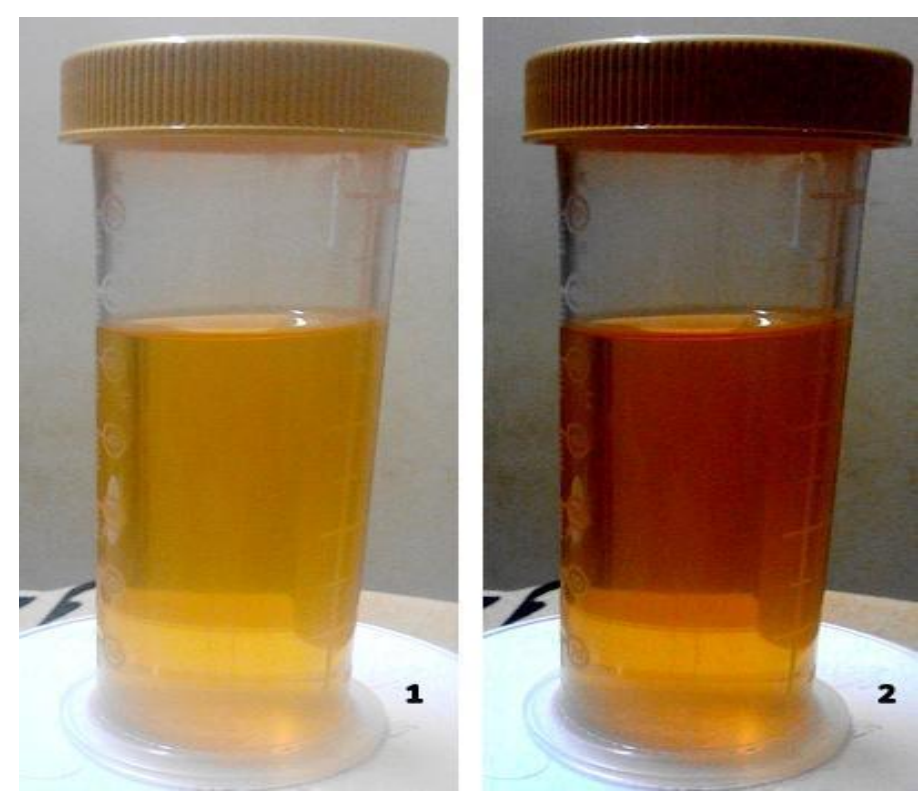

Figure. A Cow's Urine : 1. First Sample taken at 5am, 2. Sample taken at 12pm

\section{Escherichia coli DH5 Alpha}

3. Sclerotinia sclerotiorum culture (MTCC. 8785)

4. Penicillium expansum culture (MTCC. 8241)

\section{Methods \& Tests}

\section{Preparation Methods}

Preparation of Cow's urine sample:

Fresh urine samples were collected from the cattle breed in Palakkad district of Kerala, and Bangalore, Karnataka, and refrigerated in closed, air-tight, sterilized containers, to prevent oxidation. These samples were filtered and cleared from any other particulates before being used as the test material.

Note: It was ensured that the urine sample collected was the first urine micturated early morning once the cattle were awakened.

\section{Preparation of Micro-organism cultures:}

For preparing the Sclerotinia and Penicillium cultures, the MTCC culture samples for both were purecultured and sub-cultured to obtain pure strains of Sclerotinia sclerotiorum and Penicillium expansum cultures. Sub-cultures were prepared using techniques of both streak and slant cultures. Escherichia coli DH5 Alpha cells were pure-cultured using Luria Bertani Medium (LB) and then sub-cultured.

Nutrient Agar and Potato Dextrose Agar (PDA) was used as the media for bacterial and fungal cultures, respectively, for all the tests using urine.

\section{Tests}

\section{Anti-Bacterial/Anti-Fungal Tests}

The main techniques used for the anti-bacterial/anti-fungal tests were - the pour-plate test (for both bacteria and fungi) and the well-plate test (for bacteria).

In the pour-plate technique for anti-fungal test, $500 \mu 1 / 1000 \mu 1$ of cow's urine sample was pour-plated with the PDA mixed with a pinch of ampicillin, in autoclaved petridishes. These plates were then spread with the spores of Sclerotinia sclerotiorum and Penicillium expansum from pure cultures, and kept aside undisturbed for 4-5 days to observe the fungal growth pattern.

For anti-bacterial test, $1 \mathrm{ml}$ of cow's urine sample was pour-plated with the nutrient agar, in autoclaved petridishes. A fine superficial spread of DH5 Alpha bacteria from pure cultures was made on these plates and kept aside undisturbed for 24 hours to observe the bacterial growth pattern.

In the well-plate technique for anti-bacterial test, $100 \mu 1$ of cow's urine sample was micropipetted into wells within the Nutrient agar, in autoclaved petridishes. These plates had already been pre-spread with a fine superficial layer of DH5 Alpha bacteria from pure cultures. The plates were kept aside undisturbed for 24 hours to observe the bacterial growth pattern. 
Note: For each of the above techniques, control plates were maintained separately. Figures B and C illustrate the plates and the results observed, for the tests above.
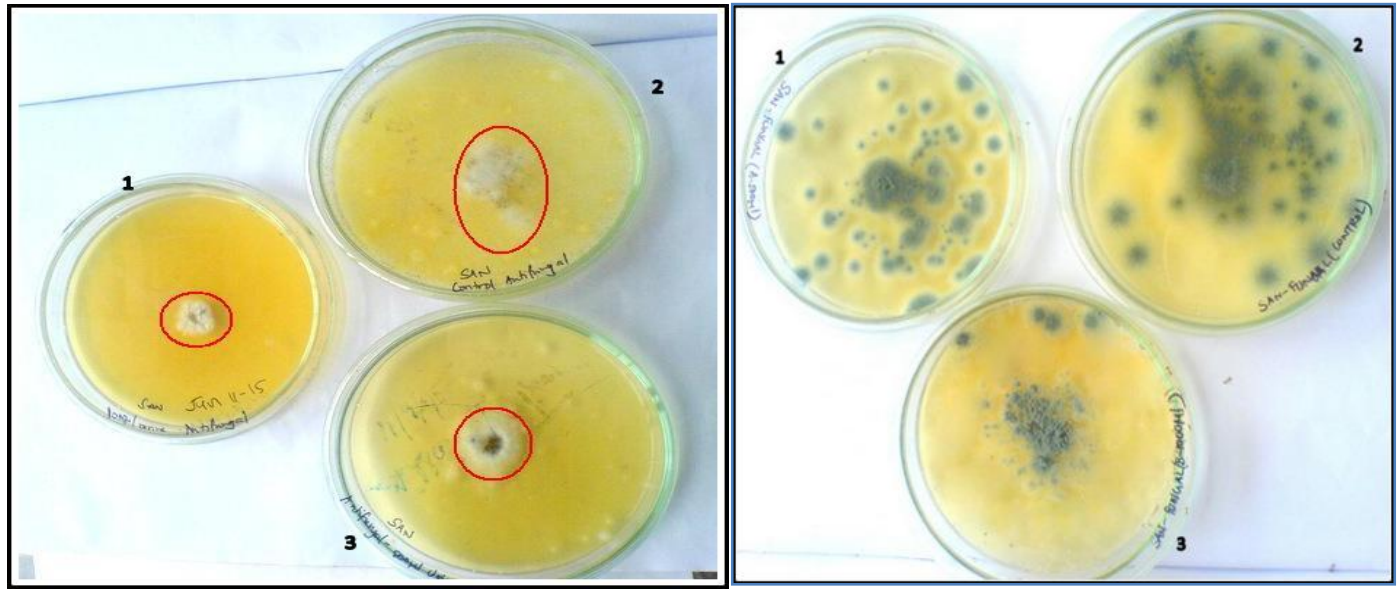

Figure. B Antifungal Test Results : (Left-hand Side) Sclerotinia 1. Fungal Growth in 1000 $\mu$ l of cow's urine sample, 2. Control 3. Growth in 500 $\mu$ l of cow's urine sample. (Right-hand Side) Penicillium 1. Fungal Growth in 500 $\mu$ l of cow's urine sample, 2. Control 3. Fungal Growth in $1000 \mu$ l of cow's urine sample.

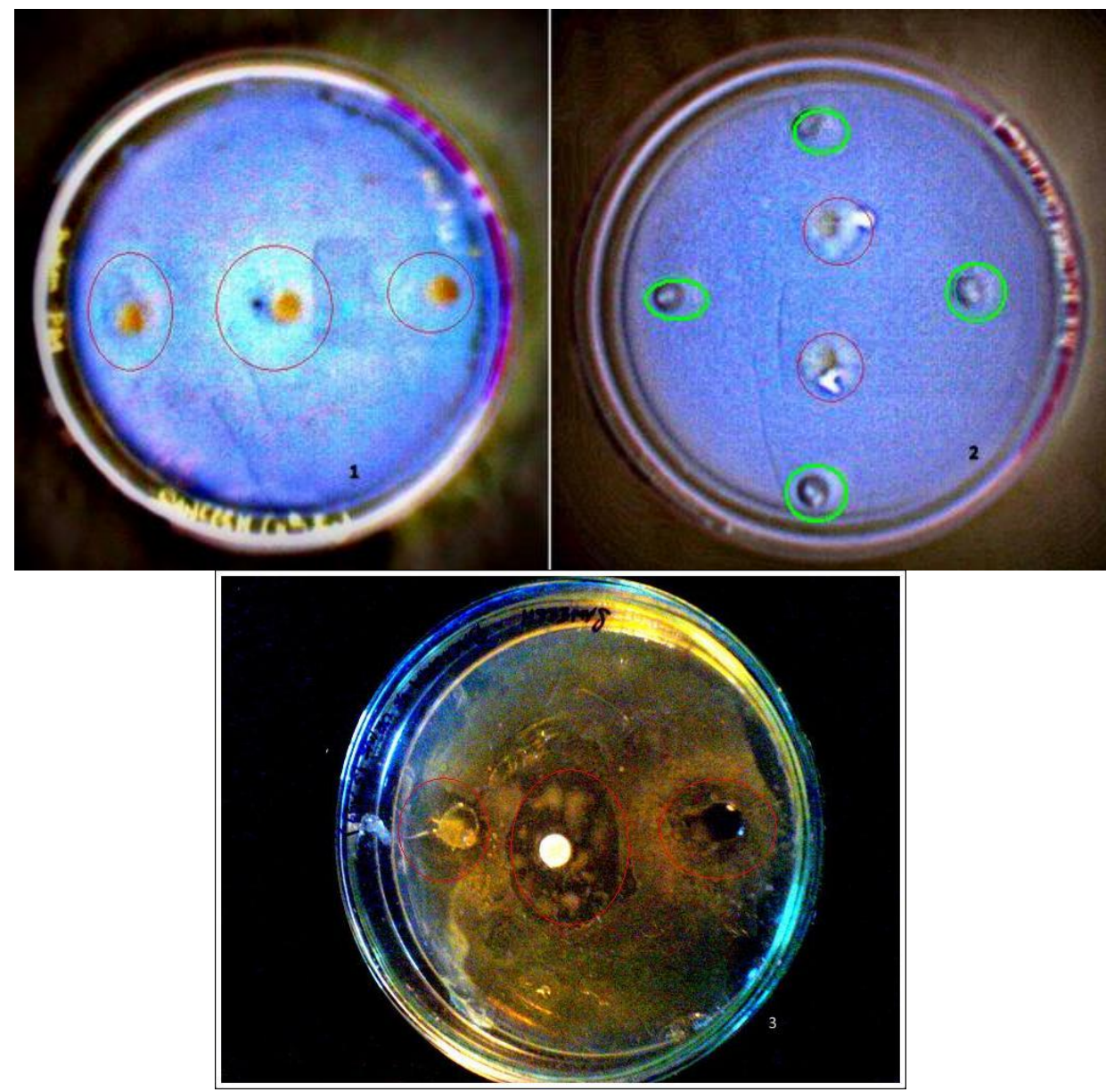

Figure. C Antibacterial Test Results : 1. UV vision of zone formation well-plating DH5-Alpha bacteria with 500 $\mu$ l of cow's urine sample, 2. Comparision of zone formation well-plating DH5-Alpha bacteria with cow's urine sample (marked red) and antiobiotics (marked green) 3. Comparision of zone formation well-plating DH5-Alpha bacteria with cow's urine sample (corner) and streptomycin (centre). 


\section{Thin Layer Chromatography (TLC) Analysis of Cow's Urine for Enzyme Detection}

Silica Gel slides were prepared by introducing silica gel of thick sloth-like consistency, on clean slides and leaving the slides undisturbed for solidification. Cow's urine sample drop was introduced (spotted) on one edge of each of the slides, and then these slides were slightly immersed in the running solvent comprising chloroform to acetic acid in the proportion 8:2. ${ }^{[10] . ~[11] . ~ T h e ~ s l i d e s ~ w e r e ~ l e f t ~ u n d i s t u r b e d ~ f o r ~ 30-45 ~ m i n, ~ a n d ~ t h e n ~}$ sprayed with ninhydrin solution on the spotted areas within each slide, and left in hot air oven for drying. The pink color observed on the spotted areas indicated presence of proteins, which confirmed the presence of an enzyme (Fig. D).

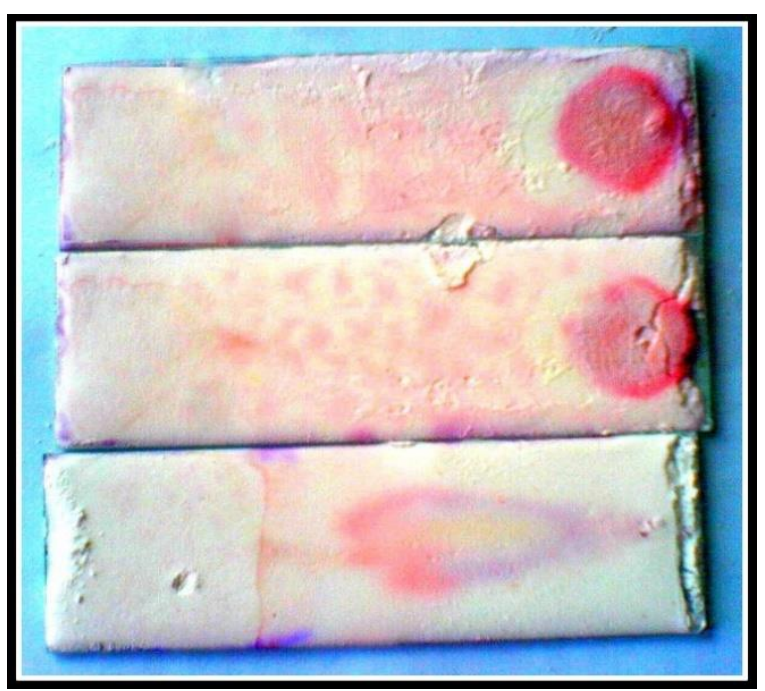

Figure. D TLC slides sprayed with ninhidryin solution, displaying the pink spots (indicating the presence of proteins in cow's urine sample)

\section{Analysis for Enzyme Detection in Cow's Urine}

Few drops of cow's urine were added to milk taken in a petridish. There was no formation of a clear zone, which confirmed the absence of protease enzyme in urine.

\section{Lipase Assay -Titrimetric Analysis}

Lipase activity was determined by incubating a reaction mixture containing $5 \mathrm{ml}$ of olive oil emulsion, $5 \mathrm{ml}$ of $0.1 \mathrm{M}$ Tris-Hydrochloride (Tris- $\mathrm{HCl}$ ) buffer at $\mathrm{pH} 8.5$, and $1.0 \mathrm{ml}$ of the filtered urine sample at $30^{\circ} \mathrm{C}$ for $20 \mathrm{~min}$, centrifuged at $120 \mathrm{rpm} .{ }^{[12]}$. After incubation, the reaction was stopped by the addition of $10 \mathrm{ml}$ of acetone and the liberated free fatty acids were titrated with $0.05 \mathrm{~N}$ Sodium Hydroxide $(\mathrm{NaOH})$ in the presence of phenolphthalein as an indicator (pale pink shade end point - Fig. E). The blank assays were performed by adding the extract just after the addition of the acetone solution to the flask. One unit of lipase activity was defined as the amount of enzyme that liberated $1 \mu \mathrm{mol}$ of fatty acids per minute under assay conditions. All experiments were carried out in duplicate, to ensure consistency in the titer values.

The lipase activity was calculated using the standard formula below:

Lipase activity (in units) $=[($ Titre value of test solution $(\mathrm{mL})$ - Titre value of blank solution $(\mathrm{mL})) \times$ Molarity of $\mathrm{NaOH} \times 1000 \times 2 \times$ Dilution factor] / [Vol. of the Test Sample $(\mathrm{mL})]$

Note: Dilution factor value was calculated as 1 .

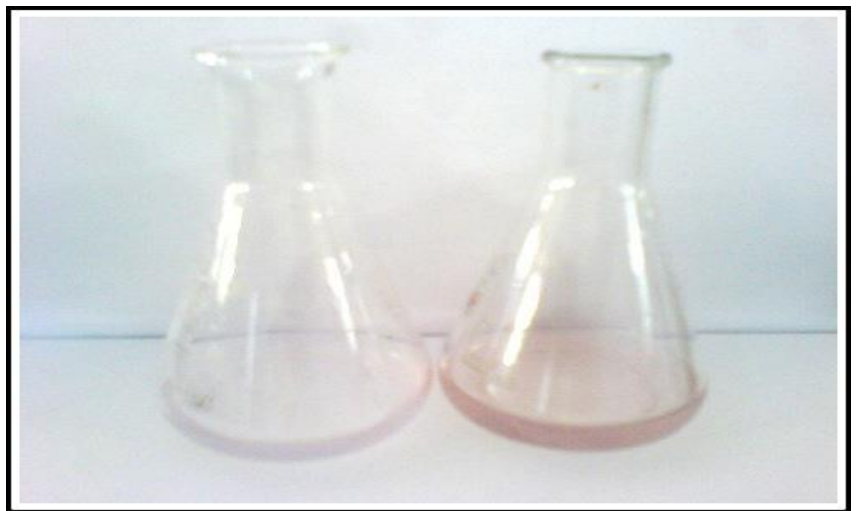

Figure. E Titration end point color change (pink shade) 


\section{UV Spectrophotometric Analysis of Cow's Urine}

The cow's urine sample was diluted by taking $1 \mu \mathrm{l}$ in $3 \mathrm{ml}$ of distilled water and centrifuging the diluted sample at $1000 \mathrm{rpm}$. The supernatant from this sample was analyzed in UV Spectrophotometer at $220 \mathrm{~nm}$ to $700 \mathrm{~nm}$. The graph readings were noted for further analysis (Fig. F, 3).

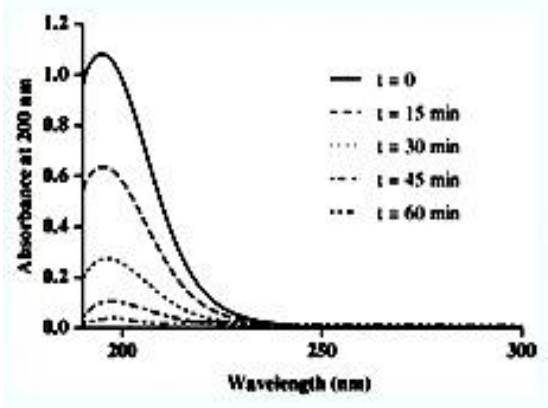

Fig. 1. Absorbence spectro during the reection of transesterkatisen betmeen why

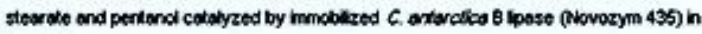
hescone.

1

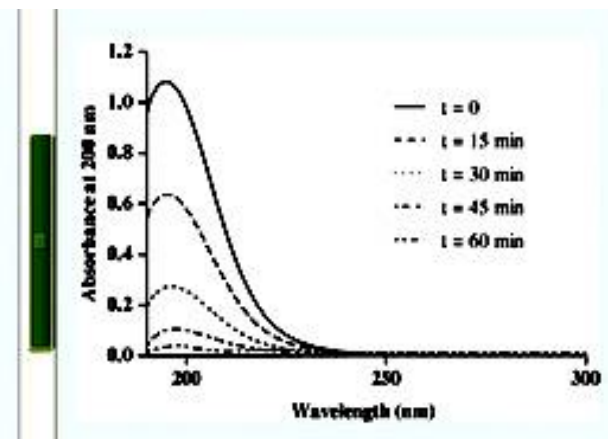

Fig. 2. Absorbance spectra during the reaction of transesteritcabion between viry

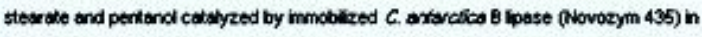
nexane.

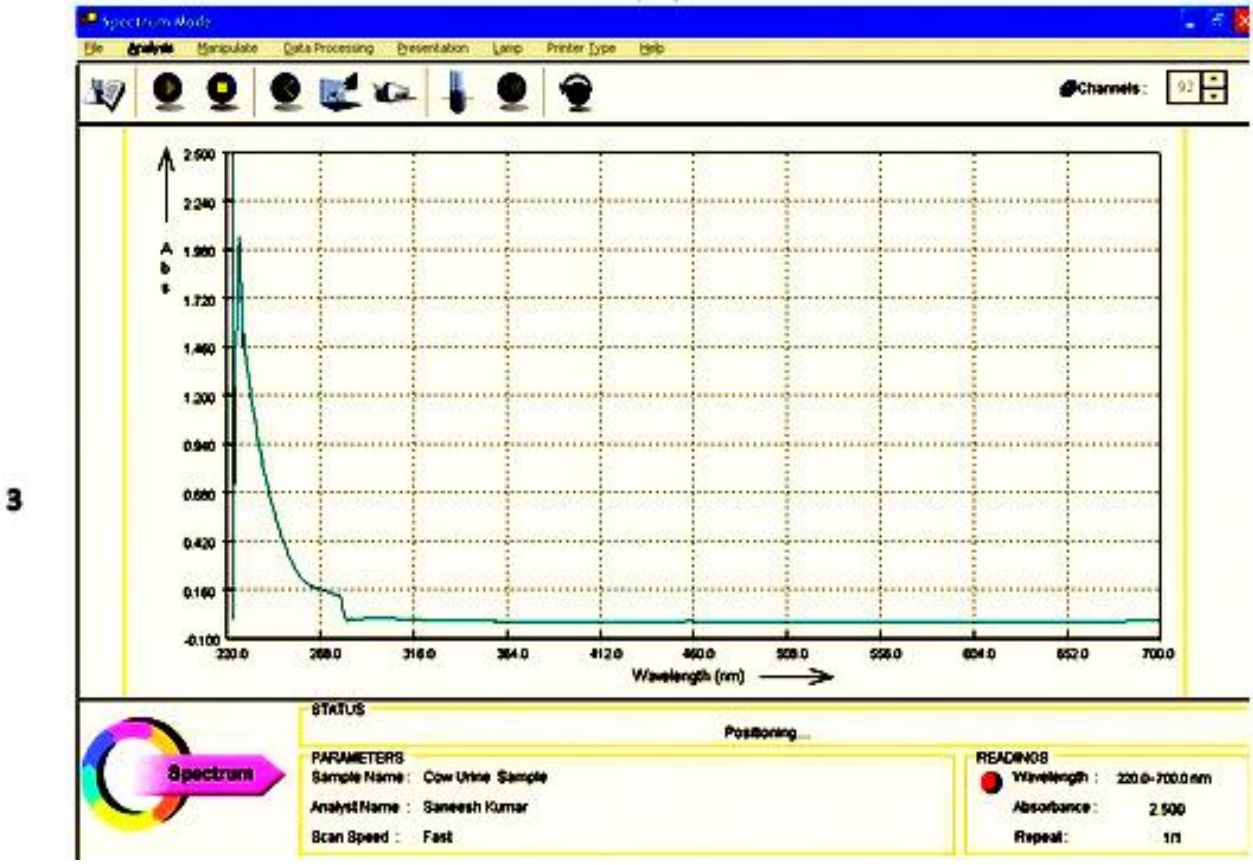

Figure. F 1, 2. Graphical illustrations of absorbance sprectra during various reactions involving immobilzed lipase. 3. Absorbance spectrum of $1 \mu \mathrm{l}$ cow's urine sample diluted in $1 \mathrm{ml}$ distilled water at 220-700nm.

\section{Tributyrin Test for Lipase Activity Confirmation in Cow's Urine}

Tributyrin Agar was originally formulated by Anderson ${ }^{[13]}$. for the detection and enumeration of lipolytic microorganisms. The same principle was implied with slight modifications in this research. The wellplate test was implicated using modified agar containing $100 \mu 1$ Tributyrin, $100 \mathrm{ml}$ distilled water and $1.6 \mathrm{~g}$ of agar.

$100 \mu 1$ of cow's urine sample was micropipetted into the wells made within the solidified agar, in autoclaved petridishes. These plates were kept aside undisturbed for 24 hours to detect and analyze lipase activity (Fig.G). 

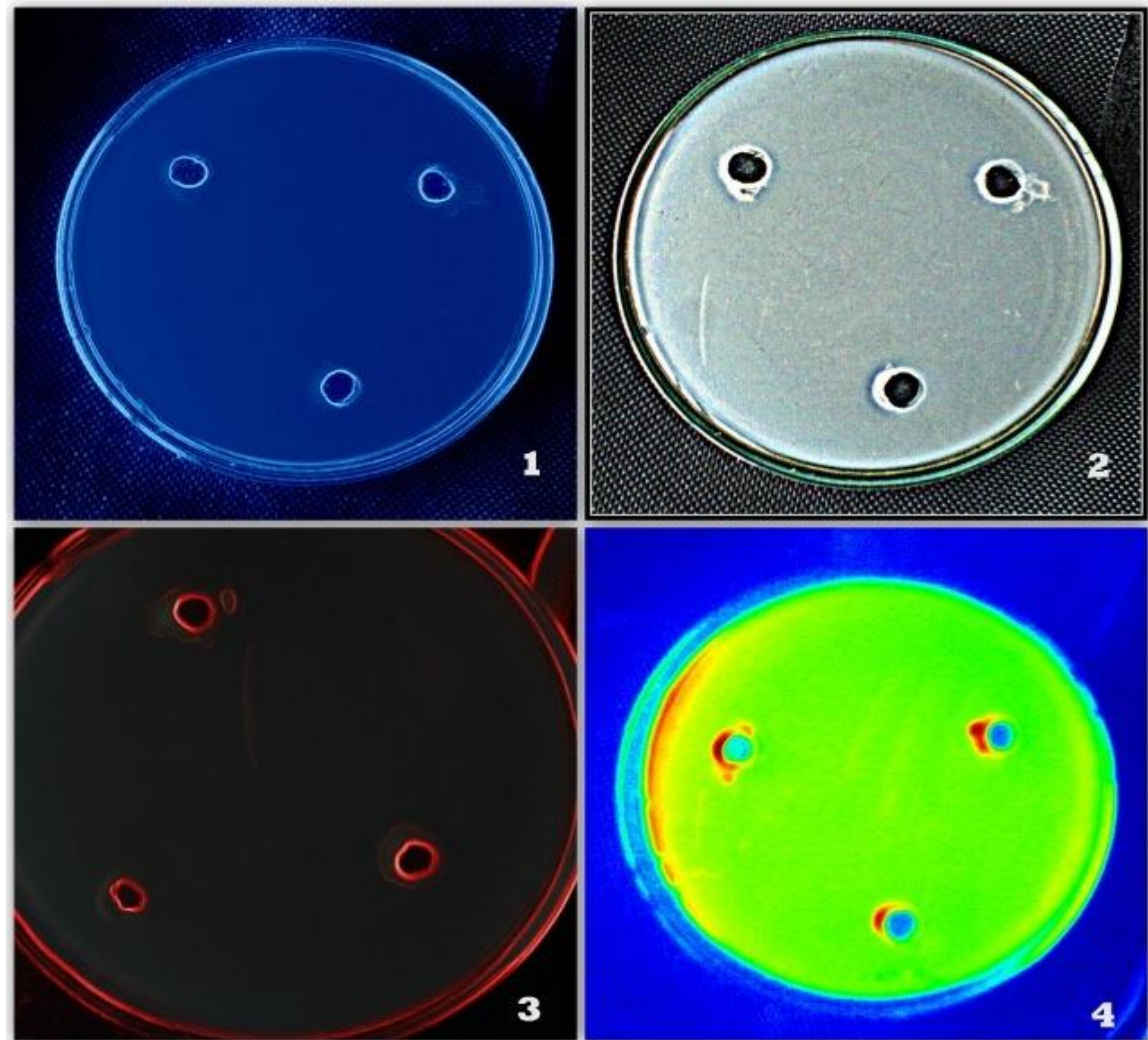

Figure. G Tributryin Test Results : 1. UV vision of zone formation well-plating Tributryin agar with $500 \mu \mathrm{l}$ of cow's urine sample, 2 . Normal vision of zone formation well-plating Tributryin agar with $500 \mu \mathrm{l}$ of cow's urine sample, 3 . Neon vision of zone formation well-plating Tributryin agar with 500 $\mu$ l of cow's urine sample, 4. Infra-red vision of zone formation well-plating Tributryin agar with $500 \mu$ l of cow's urine sample

\section{Results And Discussion}

All the analysis techniques used for biochemical analysis of cow's urine were found effective in understanding its antibacterial/antifungal properties and lipase activity levels.Cow's urine is an effective natural agent in inhibiting bacteria and fungi, and also has a high potential lipase activity too (Table 1 and 2).

Table 1 : Illustrates the Summarized results for all the tests

\begin{tabular}{|l|l|l|}
\hline \multicolumn{1}{|c|}{ Test } & \multicolumn{1}{|c|}{ Technique } & \multicolumn{1}{c|}{ Result Observed / Inference } \\
\hline Anti-Bacterial & Well-plate & $\begin{array}{l}\text { Clear inhibitory zone formation was observed around the wells which } \\
\text { indicated that cow's urine had anti-bacterial activity. The higher the } \\
\text { concentration, the more effective was the antibacterial activity levels. }\end{array}$ \\
\cline { 2 - 3 } & Pour-plate & $\begin{array}{l}\text { Reduced bacterial growth was observed compared to the control. The } \\
\text { higher the concentration, the better was the antibacterial activity levels. } \\
\text { On comparison, it was noted that fresh urine Sample 1 had more } \\
\text { inhibitory activity than the Sample 2. }\end{array}$ \\
\hline Anti-Fungal & Pour-plate & $\begin{array}{l}\text { Reduced fungal growth was observed compared to the control. The } \\
\text { higher the concentration, the better was the antibacterial activity levels. } \\
\text { On comparison, it was noted that fresh urine Sample 1 had more } \\
\text { inhibitory activity than the Sample 2. }\end{array}$ \\
\hline TLC & Chromatography & $\begin{array}{l}\text { On spraying ninhydrin solution, pink spots were observed on areas } \\
\text { within the slides where the running solvent had diffused with the urine } \\
\text { sample. This indicated the presence of amino-acids which confirmed } \\
\text { the presence of an eminent enzyme within the urine sample. }\end{array}$ \\
\hline $\begin{array}{l}\text { Volumetric Analysis of } \\
\text { Urine }\end{array}$ & Titration & $\begin{array}{l}\text { This titration value limits illustrated the fact that there was lipase } \\
\text { presence within the urine sample. }\end{array}$ \\
\hline $\begin{array}{l}\text { UV Spectrophotometric } \\
\text { Analysis }\end{array}$ & Spectrophotometry & $\begin{array}{l}\text { The graphs obtained from the sample analysis showed that lipase was } \\
\text { present within the urine sample. On comparison with other graphs } \\
\text { obtained from other Spectrophotometric studies of lipase, illustrated } \\
\text { similarities and ascertained the fact that cow's urine had lipase content. }\end{array}$ \\
\hline
\end{tabular}




\begin{tabular}{|l|l|l|}
\hline Tributyrin Agar Test & Well-plate & $\begin{array}{l}\text { Clear zone formation around the wells ascertained and confirmed the } \\
\text { fact that lipase activity within cow's urine sample was eminent and was } \\
\text { capable of breaking down the Tributyrin present within the agar } \\
\text { medium. } \\
\text { The clear distinctive zones indicated that cow's urine was an excellent- } \\
\text { natural source of lipase enzyme. }\end{array}$ \\
\hline
\end{tabular}

Table 2 : Lipase Activity Calculated in units/mL

\begin{tabular}{|l|c|}
\hline SOLUTION & TITRATION VALUE \\
\hline $\begin{array}{l}\text { Test Solution Against 50mM } \\
\text { NaOH }\end{array}$ & 8.4 \\
\hline $\begin{array}{l}\text { Blank Solution Against 50mM } \\
\mathrm{NaOH}\end{array}$ & 6.9 \\
\hline \multicolumn{2}{|c|}{ RESULT } \\
\hline $\begin{array}{l}\text { Lipase Activity in Cow's Urine } \\
\text { (in units) }\end{array}$ & $\mathbf{1 5 0}$ units/mL \\
\hline
\end{tabular}

Figure F illustrates a comparative study on the absorbance spectra of lipase enzyme. Figures 1 and 2 depict previous studies on immobilized lipase activity. ${ }^{[14]}$. [15]. On comparison with Figure 3 which is the absorbance spectra analyzed for cow's urine sample (in this research), the graphs have an affinity in character. The levels of absorbance at the wavelengths ranging from $220-300 \mathrm{~nm}$ had close similarities from those of the previous studies, indicating that there was lipase activity within cow's urine.

\section{Conclusion}

From the analysis and results recorded above, it was concluded that Cow's urine was highly effective and stable in inhibiting/ controlling the growth of fungi and bacteria. Ancient ayurvedic literatures emphasized the antimicrobial activity of Cow's urine and this research helped ascertain the fact. Also cow's urine was concluded to be one of the best natural sources of lipase enzyme. The excellent lipase activity within the urine sample makes it a highly efficient therapeutic in curing many diseases.

Purified cow's urine being used as an effective anti-bacterial/anti-fungal therapeutic since decades, as stated in ayurvedic literature; would be most effective in controlling many skin diseases. Instead of using chemicals while taking bath, a small amount of cow's urine can be added in the water as an antiseptic. The lipase activity of cow's urine makes it an efficient destroyer of fat deposits and lipophilic cells. The potential of cow's urine can be exploited as excellent cures in conditions such as obesity, blood purification, weight reduction, skin diseases, etc.

Recent research even states the exploitation of cow's urine as a possible cure for cancer. This can be ascertained based on the theory that the lipase activity of urine sample can be used to break down metastatic cell masses in cancerous conditions, thereby allowing access to the immunity system (macrophages) within the body to act on the simplified cancer cells and destroy the oncogenic ones. More research is required to achieve this new horizon of curing cancer.

The research also concludes that the early morning cow's urine sample was found to be more effective than the samples extracted at any other time. This could mainly be due to the fact that early morning sample of the urine has a higher content of enzymes, hormones and other minerals which could make it more effective anti-microbial therapeutic and an excellent source of lipase enzyme.

\section{Acknowledgement}

I am truly grateful to my professor and guide Dr. Mahesh, the CEO of Azyme Biosciences Prv. Ltd. Bangalore, for his motivation, encouragement and also for providing me the infrastructure and resources to complete my project work.

I am also grateful to Dr. Maya C Nair, Professor of Govt. Sanskrit College (Pattambi) Kerala, for her support and guidance in helping me complete this project.

Finally, I would wish to dedicate this project work to my mentor and Ayurvedic physician, respected Sri. Swami Nirmalanandha Giri Maharaj, and also my parents who have been ever-so supportive, encouraging and facilitative in all my research activities and projects.

\section{References}

[1]. K. Dhama, R. Rathore, R.S.Chauhan, S.Tomar. Panchgavya (Cowpathy): An Overview, International Journal of Cow Science 2005; $1: 1-15$.

[2]. R.S. Chauhan, K. Dhama, L. Singhal. The Indian Cow: The Scientific and Economic Journal 2009; 19:22-58.

[3]. J. Edwin, E. Sheej, T. Vaibhav, G. Rajesh, T. Emmanuel. Antioxidant and antimicrobial activities of cow urine, Global journal of pharmacology 2008; 2:20-22. 
[4]. K.J. Virender, Cow urine can cure many diseases, Articles on Ayurveda, Indore Publishers; 2009.

[5]. P.B. Flora, S.Gisela. Healing yourself using Urine. Urine Therapy: Nature's Elixir for Good Health; 1999. p. 152.

[6]. D. Nelson. India makes cola from cow urine to millions of devout Hindus, it's the real thing: a cola made from the urine of India's sacred cows,Article - The Daily Telegraph, London; 2010.

[7]. B. Andrew. A cure for cancer - or just a very political animal?Article - The Independent, United Kingdom; 2011

[8]. H. Bhadauria. Cow Urine- A Magical Therapy. Vishwa Ayurveda Parishad, Int J Cow Sci. 2002; 1:32-6.

[9]. R.S. Chauhan. Panchagavya Therapy (Cowpathy)- Current status and future directions. Indian Cow 2004; 1:3-7.

[10]. J. Sherma, D.W. Gruenwedel,J.R. Whitaker. Separation Techniques, Food Analysis - Principles and Techniques, Marcel Dekker, New York; 1987. p. 297.

[11]. A.R. Shalaby, B. Fried, J. Sherma. Practical Thin Layer Chromatography - A Multidisciplinary Approach, CRC Press, Boca Raton, FL; 1996. p. 169.

[12]. G.A. Macedo, Y.K. Park, G.M. Pastore. Partial purification and characterization of an extracellular lipase from a newly isolated strain of Geotrichum sp.,Rev. Microbiol 1997; 28:90-95.

[13]. J.A. Anderson, Ber. III ${ }^{\text {rd }}$ Int. Mikrobiol,Kongress 1939; 3:726

[14]. M. Shuichi, Y. Hiromi, M. Rina, N. Tomohiro, E. Yasuhito, U. Shin-ichi. A method to greatly improve the enantioselectivity of lipase-catalyzed hydrolysis using sodium dodecyl sulfate (SDS) as an additive Original Research Article, Tetrahedron: Asymmetry 2005; 22:3698-3702.

[15]. D.B. Carlos, T. Anatoli, G. George, T. Tzanko. Light harvesting amphiphiles boost the performance of lipase-based washing formulations Original Research Article, Enzyme and Microbial Technology 2012; 3:156-162. 